\section{Pengantar $\theta$ Pendidikah}

Buku ini membahas tentang sejarah pendidikan, hakikat pendidikan, dan perubahan dalam ruang lingkup masyarakat untuk menentukan jalan hidupnya memilih sebuah pendidikan yang mencerdaskan.

Buku ini membahas tentang sebuah hakikat pendidikan yang membantu peserta didik dapat bersaing dalam bidang IPTEK dan sekaligus memberikan sebuah pelajaran proses agar mereka bisa menjadi tauladan yang yang baik, baik dalam lingkungan keluarga maupun masyarakat sekitar.

Pendidikan menjadi salah satu perhatian bagi masyarakat, pendidikan merupakan arena untuk mengasah akal, mempertajam akal, dan mengembangkan intlektualitas, pendidikan dapat mengidentifikasi berbagai problem yang dihadapi oleh masyarakat, terutama yang berkaitan dengan persoalan budaya, intlektualitas, dan berbagai fenomena politik, tetapi dengan pendidikan yang modern masyarakat bisa melakukan perubahan pembaruan, pendidikan bisa menjelma menjadi kekuatan transformasi dan perubahan.

\section{Book Chapter}

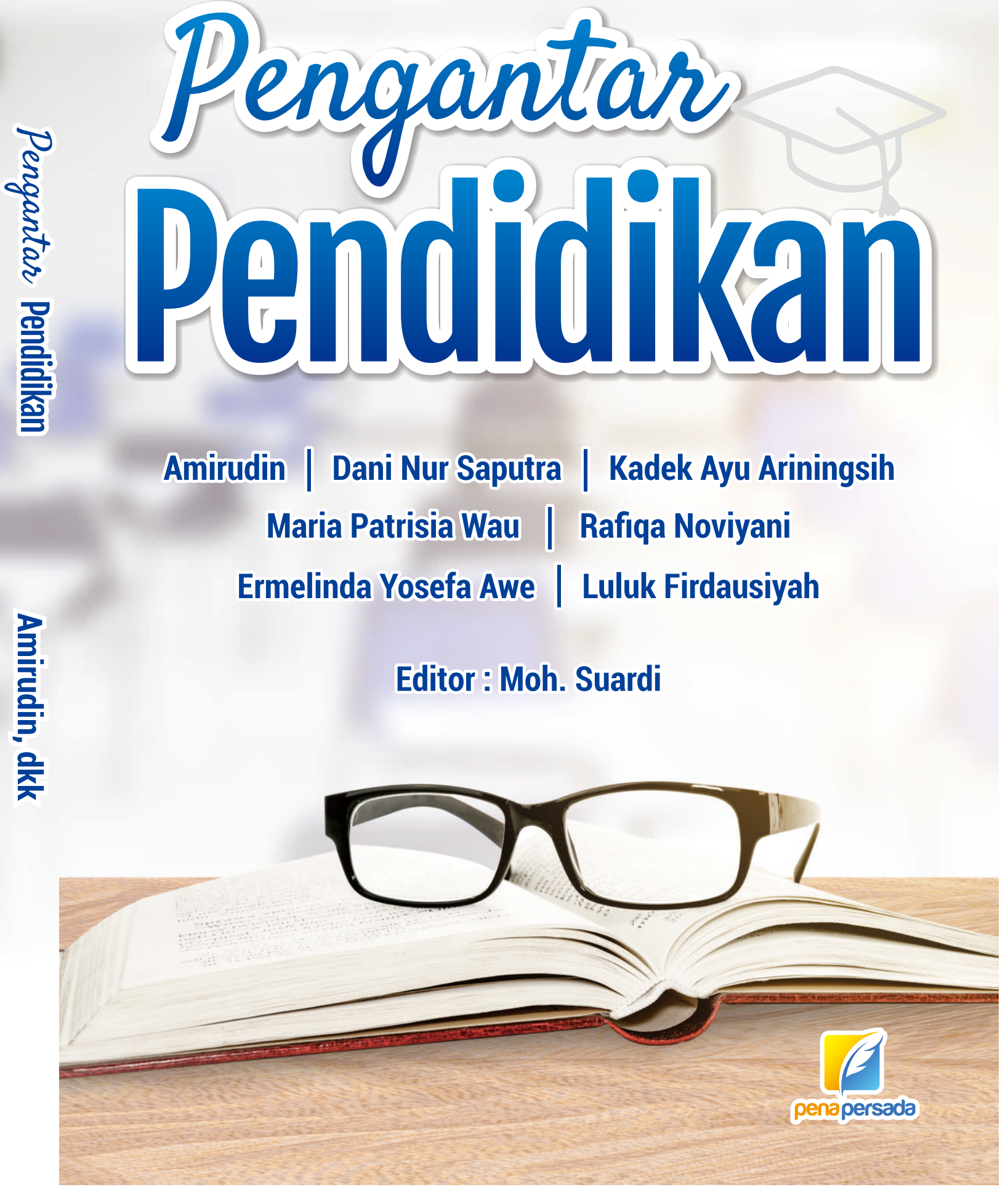




\title{
BOOK CHAPTER PENGANTAR PENDIDIKAN
}

\author{
Amirudin \\ Dani Nur Saputra \\ Kadek Ayu Ariningsih \\ Maria Patrisia Wau \\ Rafiqa Noviyani \\ Ermelinda Yosefa Awe \\ Luluk Firdausiyah
}

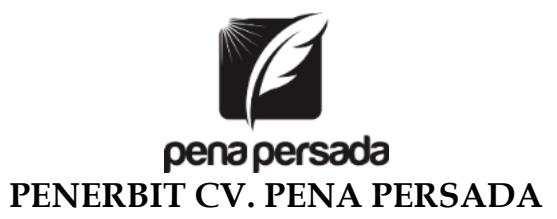




\title{
BOOK CHAPTER \\ PENGANTAR PENDIDIKAN
}

\author{
Penulis: \\ Amirudin \\ Dani Nur Saputra \\ Kadek Ayu Ariningsih \\ Maria Patrisia Wau \\ Rafiqa Noviyani \\ Ermelinda Yosefa Awe \\ Luluk Firdausiyah
}

ISBN: 978-623-315-520-5

\section{Editor:}

Moh. Suardi

Design Cover:

Retnani Nur Briliant

Layout:

Nisa Falahia

\section{Penerbit CV. Pena Persada}

Redaksi:

Jl. Gerilya No. 292 Purwokerto Selatan, Kab. Banyumas

Jawa Tengah

Email: penerbit.penapersada@gmail.com

Website: penapersada.com Phone: (0281) 7771388

\section{Anggota IKAPI}

All right reserved

Cetakan pertama: 2021

Hak Cipta dilindungi oleh undang-undang. Dilarang memperbanyak karya tulis ini dalam bentuk apapun tanpa izin penerbit 


\section{KATA PENGANTAR}

Puji syukur penulis panjatkan kepada Allah Swt atas berkat rahmat dan karunianya penulis buku Book Chapter Pengantar Pendidikan ini dapat di selesaikan sesuai dengan rencana, buku ini dapat di manfaatkan oleh mahasiswa pendidikan, di Iintitut Kegurruan dan Ilmu Pendidikan, maupun Universitas yang ada jurusan pendidikan dan para pemerhati pendidikan.

Book Chapter Pengantar Pendidikan disusun untuk kepentingan sebagai buku pegangan yang diikhtiarkan untuk membantu para mahasiswa dan dosen yang menempuh mata kuliyah Pengantar Pendidikan, Belajar dan Pembelajaran, oleh karena itu buku ini berdasarkan dan dirumuskan sesuai dengan Rencana pembelajaran di Fakultas Keguruan dan Ilmu Pendidikan di semua Universitas atau IKIP yang berhubungan dengan Pendidikan.

Secara tradisi di Indonesia mata kuliah Pengantar Pendidikan, Belajar dan Pembelajaran yang di berlakukan di Fakultas Keguruan dan pendidikan atau LPTK dapat disajikan pada semester awal atau semester dua yang mengawali sekaligus membekali para mahasiswa yang akan memepelajari dan mendalami tentang ilmu pendidikan.

Pendidikan adalah merupakan sebuah proses perubahan sikap dan perilaku seseorang atau kelompok melalui sebuah sistem pengajaran dan pelatihan tertentu, tujuan pendidikan suatu bangsa di sesuaikan dengan kepentingan bangsa itu sendiri, pendidikan dapat kita implementasikan sebagai revolusi industri yang dapat merubah cara pikir dan tingkah laku sesuai dengan mdel pendidikan saat ini.

Setelah membaca buku ini kita akan mendapatkan narasinarasi baru tentang pendidikan sehingga bisa merubah polah dan kehidupan dalam berpendidikan. Pada masyarakat yang cukup sederhana maka mutu pendidikannya pun cukup sederhana, pada masyarakat yang sedehana inilahpandangan 
pendidikan yang harus kita optimalkan untuk mengembangkan pendidikan.

Pendidikan dapat dimaknai upaya-upaya untuk menanamkan nilai-nilai dalam keseluruhan proses pembelajaran untuk mencapai suatu tujuan tertentu untuk mengawali dan mengembangkan pendidikan bisa-bisa melalui kajian-kajian tentang pemikiran-pemikiran pendidikan atau Great Book learning.

Pemahaman tentang kebijakan masih dianggap sama dengan kebijksanaan, kebijakan dan kebijksanaan ketika kita melihat hamper sama namun sebenarnya kedua kata itu berbeda. Kebijakan berasal dari kata bijak, sedangkan kebijaksanaan berasal dari Bijaksana. Kebijakan adalah merupakan sebuah hsail tertulis yang berupa hasil keputusan formal yang dikeluarkan oleh lembaga- lembaga yang memiliki otoritas untuk mengeluarkannya, sedangkan kebijaksanaan merupakan sebuah nilai kearifan dan nilai-nilai yang dimiliki seseorang terutama kepada pemimpin atau kepada orang yang dituakan di sekitar kita.

Arah dan kebijakan kurikulm merupakan sebuah implementasi pelaksanaan proses pendidikan yang selama ini cenderung hanya dalam bidang aspek kognitif, kebijakan kurikulum ini merupakan sebuah inovasi pendidikan sebagai bagian dari kemajuan pikiran anak bangsa untuk mewujudkan pendidikan yang lebih bermutu. Kebijakan kurikulum baru banyak menawarkan konsep dan gagasan baru dalam merubah pendidikan menjadi lebih baik.

Buku ini selain mengupas tentang pengertian pendidikan dan juga mengupas tentang arah dan kebijakan kurikulum, walaupun kita akui masih banyak kita jumpai kendalakendala terutama dalam kesiapan dan kemampuan dalam sumber daya manusia dalam menentukan arah kebijakan kurikulum, arah kebijakan kurilulum ini tidak tidak lepas dari kebijakan-kebijakan politik demi efektifitas kebijakan kurikulum. 
Buku ini kami sajikan jauh dari sempurna sehingga kritik dan saran dari pembaca sangat di butuhkan untuk menyempurnakan tulisan dalam buku ini, semoga buku ini bisa memberikan sumbangan buat para pemangku kebijakan, praktisi pendidikan dan pihak-pihak lain yang menjalankan tugas dan tanggung jawabnya sebagai seorang pendidik.

Akhirnya kepada pembaca yang budiman saran dan kritiknya yang membangun sangat penulis harapkan demi perbaikan buku ini kedepannya

Padang Juli 2021

Editor 


\section{DAFTAR ISI}

KATA PENGANTAR .......................................................... ii

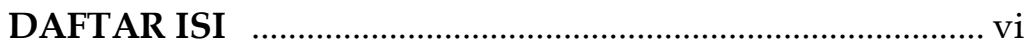

BAB 1. Sejarah Pendidikan

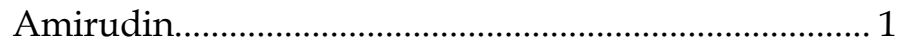

BAB 2. Permasalahan Pokok Pendidikan

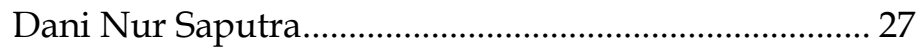

BAB 3. Hakikat Manusia dan Pengembangan Melalui

Pendidikan

Maria Patrisia Wau

BAB 4. Hakikat Pendidikan

Kadek Ayu Ariningsih

BAB 5. Lingkungan Pendidikan

Rafiqa Noviyani 61

BAB 6. Pendidikan dan Kebudayaan

Ermelinda Yoesefa Awe 77

BAB 7. Kurikulum Pendidikan

Luluk Firdausiyah 90 


\title{
BAB 1 \\ SEJARAH PENDIDIKAN
}

\author{
Amirudin \\ Dosen Universitas Muhammadiyah Prof. Dr. HAMKA Jakarta
}

\section{A. Pendahuluan}

Perjalanan sejarah pendidikan menurut Dieter Lenzen, presiden Freie Universität Berlin (1994), "telah berlangsung sejak jutaan tahun" (http://en.wikipedia.org/wiki/ Education). Pernyataan Lenzen ini sangat logis jika kita menerima bahwa sejatinya pendidikan secara informal telah dimulai sejak penciptaan Adam sebagai manusia pertama (Yusuf, 2018). Pendidikan membentuk manusia menghasilkan peradaban yang tinggi dari masa ke masa karena penguasaannya terhadap ilmu pengetahuan. Tanpa pendidikan, manusia tidak akan mampu mengeksplorasi rahasia-rahasia yang terdapat dalam fenomena alam semesta. Olehkarena itu dapat dikatakan bahwa, semakin maju pendidikan yang dicapai oleh suatu masyarakat, maka akan semakin tinggi pula peradaban yang dibangunnya.

Pendidikan dan sejarah tidak dapat dilepaskan satu sama lain karena keduanya memiliki fungsi intrinsik yang sama (Helius Sjamsuddin, 2017). Walaupun para sejarawan tidak bersepakat adanya definisi yang sama, namun paling tidak ada tiga definisi yang dapat diajukan untuk memberi guidance dalam kaitannya dengan topik ini. Pertama James Harvey Robinson dalam The New History, mendefinisikan bahwa sejarah adalah semua yang diketahui manusia tentang setiap hal yang telah dilakukan, dipikirkan, atau dirasakan" (Robinson, 1912). Kedua mengutip Kochhar (2008), mengatakan bahwa, pembelajaran sejarah bersifat 
kronologis, yang merupakan kunci dalam memahami masa lalu dan masa sekarang. dan Ketiga menurut Hasan (dalam Kurniawati, 2015), mengemukakan bahwa; mempelajari sejarah merupakan media yang paling ampuh dalam memperkenalkan masa lampau dan tantangan yang dihadapi siswa dimasa kini dan akan datang.

Dari tiga definisi tentang sejarah pendidikan, dapat sintesiskan bahwa mempelajari sejarah pendidikan adalah suatu cara memperkenalkan dinamika sejarah pendidikan dimasa lampau secara kronologis sehingga dapat mengetahui akibat yang ditimbulkan oleh peristiwa-peristiwa masa lampau itu pada masa sesudahnya dan juga pada masa kini. Selanjutnya pada bab ini, akan menguraikan beberapa sub pokok bahasan; Bagian I. Sejarah Pendidikan Dunia, yang meliputi; a) Pendidikan Masa Klasik, b) Pendidikan Abad Pertengahan, dan c) Pendidikan Abad Moderen. Bagian II. Sejarah Pendidikan di Indonesia, meliputi; a) Pendidikan Masa Hindu-Budha, b) Pendidikan di Indonesia pada Zaman Penyebaran Islam, c) Pendidikan Masa Kolonialisme, b) Pendidikan Masa Perjuangan Bangsa, c) Pendidikan Masa Pembangunan dan Reformasi.

\section{B. Sejarah Pendidikan Dunia.}

\section{Perkembangan Pendidikan Masa Klasik}

\section{a. Pendidikan Yunani}

Masa Yunan Kuno merupakan masa awal kebangkitan filsafat di dunia karena pada masa ini kepercayaan terhadap mitologi atau tahayyul secara berangsur-angsur ditinggalkan menuju cara berpikir yang rasional. Filsafat Yunani Kuno merupakan periode yang sangat penting bagi sejarah peradaban manusia karena waktu pola pemikiran manusia masih 
mengandalkan mitos untuk menjelaskan fenomena alam.

Bangsa Yunani kuno terbagi menjadi dua, Sparta dan Athena. Penduduk Sparta disebut bangsa Doria, sedangkan penduduk Athena disebut bangsa Onia. Kedua negara tersebut merupakan polis atau negara kota. Sparta dengan ahli negaranya Lycurgus, sedang Athena dengan ahli negaranya Solon. Pada kedua negara tersebut terdapat perbedaan mendasar dalam hal; dasar pendidikan, tujuan pendidikan serta pelaksanaan pendidikan dan pengajaran. Pertama Sparta. Pendidikan Sparta mementingkan pembentukan jiwa patriotik yang kuat dan gagah berani (Djumhur, 1974).

Ciri pendidikan Sparta adalah: Pendidikan diselenggarakan oleh negara dan hanya untuk warga negara merdeka. Model pelaksanaan pendidikan Sparta adalah: anak-anak dibiasakan menahan lapar, tidur di atas bantal rumput, dan pada musim dingin hanya memakai mantel biasa saja. Sifat-sifat yang yang ditanamkan dalam sistem pendidikannya adalah mengikuti pola yang dimiliki tentara, seperti keberanian, ketangkasan, kekuatan, cinta tanah air, dan tunduk pada disiplin. Sebaliknya, pelajaran seperti kesenian dianggap tidak terlalu penting dan diabaikan. Musik dan nyanyian hanya dijadikan alat untuk mempengaruhi jiwa dalam melaksanakan dinas ketentaraan (A. Ahmadi, 1987).

Kedua Athena. Athena adalah negara demokrasi. Dasar yang dipakai adalah: Undang-undang Solon ( \pm 594 SM). Berbeda dengan Sparta, tujuan pendidikan Athena adalah: membentuk warga negara dengan jalan pembentukan jasmani dan rohani yang harmonis (selaras). Ciri-ciri pendidikan di Athena adalah: a) Pendidikan diselenggarakan oleh keluarga dan 
sekolah; b) Sekolah diperuntukkan bagi seluruh warga negara (bebas). Materi atau bahan pelajaran terbagi atas dua bagian: gymnastis dan muzis. Gymnastis untuk pembentukan jasmani, sedangkan muzis untuk pembentukan rohani. (Djumhur, 1976).

Ahli-Ahli Pendidik Yunani antara lain:

1) Pythagoras (580-500 SM). Tujuan pendidikannya adalah; membentuk manusia susila dan beragama. Cita-cita yang menjadi dasar pendidikannya: a) hanya jiwa yang berharga, bukan badan; b) jiwa berasal dari dewa-dewa dan hidup terus jika badan telah mati; c) sejak kecil manusia mempunyai kecenderungan untuk berbuat jahat, pendidikan harus membawa manusia ke arah kesempurnaan, dan d) kesempurnaan adalah kebajikan, yaitu keselarasan antara jiwa dan raga, harmoni dalam hubungan antara manusia, harmoni pula dalam negara.

2) Socrates (469-399 SM) merupakan tokoh yang melawan ajaran sofisme. Ia berpendapat bahwa yang menjadi ukuran segala-galanya bukan manusia melainkan ke-Tuhanan (theosentris, theo: Tuhan). Berlawanan dengan Pythagoras, Socrates percaya bahwa manusia mempunyai pembawaan untuk berbuat baik. Socrates berpendapat bahwa ilmu adalah sumber dari kebajikan, oleh karena itu ia dianggap perintis kaum philantropin: cinta pada sesama manusia. Dalam pelaksanaan pengajarannya, dia melakukan dialog, percakapan, dan tanya jawab dengan masyarakat di jalan-jalan, di taman, dan pasar.

3) Plato (427-347 SM). Plato adalah murid Socrates. Ia adalah seorang bangsawan. Saat Socrates dijatuhi hukuman minum racun, Plato melarikan diri dan mendapat perlindungan dari keluarganya. Sistem 
pendidikan yang lengkap dan merupakan bagian dari ajaran ketatanegaraan pertama disusun oleh Plato, ia adalah seorang pengarang pertama di Yunani. Tujuan pendidikan menurut Plato adalah: membentuk warga negara secara teoritis dan praktis. Setiap manusia bertugas untuk mengabdikan kepentingannya kepada kepentingan negara. Oleh sebab itu pendidikan harus diselenggarakan oleh negara dan untuk negara. (Achmadi, 1987).

4) Aristoteles (384-322 SM) adalah murid dari Plato dan telah berguru selama 20 tahun. Bukunya yang terkenal mengenai cita-cita pendidikan adalah: Politica dan Anima. Seperti halnya dengan Plato, maka Aristoteles pun menghendaki pendidikan negara. Cita-cita pendidikannya: kebajikan itu diperoleh dengan jalan aman, melalui pengalaman, pembiasaan-pembiasaan, akal budi, dan pengertian. Pendidik harus mempelajari dan memimpin pembawaan dan kecenderungan anakanak. Dengan latihan dan pembiasaan mereka diajar melakukan perbuatan yang baik dan meninggalkan yang buruk. Menurutnya sumber pengetahuan adalah pengalaman, pengamatan, yang menghasilkan bahan untuk berpikir.

\section{b. Pendidikan Romawi}

Pendidikan Romawi tampak lebih sederhana dan lebih disesuaikan dengan kebutuhan negara jika dibandingkan dengan pendidikan Yunani. Roma yang pada awalnya adalah negara petani, mengalami dua masa yang masing-masing berbeda baik tujuan maupun alat-alat pendidikannya, yaitu jaman Romawi lama dan jaman Romawi baru (Hellenisme). pertama Pendidikan pada zaman Romawi Lama bertujuan 
membentuk warganegara yang setia dan berani, siap berkorban membela kepentingan tanah airnya. Diutamakan pembentukan warganegara yang cakap sebagai tentara. Pendidikan diselenggarakan oleh keluarga, dan merupakan pendidikan bangsawan bukan pendidikan rakyat. Materi pelajarannya meliputi membaca, menulis, dan berhitung. Pendidikan jasmani dan kesusilaan menjadi prioritas.

Kedua Zaman Romawi Baru (Helenisme). Hellenisme adalah aliran kebudayaan yang diciptakan oleh ahli-ahli filsafat Yunani (Hellas). Sejak saat itu bangsa Romawi mulai menyadari arti penting ilmu pengetahuan. Dengan demikian, maka tujuan pendidikan mengalami perubahan: untuk pembentukan manusia yang harmonis. Pendidikan ratio dan kemanusiaan (humanitas) menjadi prioritas. Organisasi sekolah yang dibentuk meliputi: a) sekolah rendah: pelajarannya membaca, menulis, dan berhitung. Musik dan menyanyi tidak mendapat perhatian; b) sekolah menengah: pelajarannya ilmu pasti, ilmu filsafat, dan kesusasteraan klasik; c) sekolah tinggi: diberikan keahlian pidato, hukum, dan undang-undang.

Ketiga Zaman Agama Kristen. Agama Kristen menandai satu perubahan dengan membawa unsurunsur baru: a) tujuan hidup manusia tidak terletak di dunia fana ini seperti tujuan kebudayaan klasik Yunani dan Romawi, tetapi di alam baqa kelak; b) berbeda dengan kebudayaan klasik yang mengenal banyak dewa, agama kristen hanya mengakui adanya satu Tuhan (monotheisme); c) dalam pandangan agama ini, pendidikan tidak hanya untuk golongan tertentu saja, melainkan untuk semua manusia (umum). Pada jaman ini dapat dibedakan menjadi 2 golongan sekolah, yaitu: a. sekolah-sekolah kristen; $b$. 
sekolah kafir/ jahiliyah. Yang termasuk kategori sekolah kristen adalah sekolah catechumeen (sekolah pendengar) yang tujuannya menarik dan mendidik orang-orang yang masuk agama kristen.

\section{c. Pendidikan Mesir Purba}

Mesir purba telah mengenal peradaban yang tinggi. Tanahnya didiami oleh rakyat yang cerdas dan tahu akan harga diri. Penduduknya terdiri dari beberapa golongan yang masing-masing mempunyai tugas hidup sendiri-sendiri (pembagian kasta). Kasta yang paling berkuasa ialah kasta pendeta. Pada tahun 31 SM Mesir menjadi suatu bagian dari negara Romawi. Agamanya adalah polytheisme (menyembah banyak dewa). Tulisannya terkenal dengan nama hieroglyph (artinya adalah tulisan suci), sampai sekarang masih banyak disimpan orang. Tulisan itu biasanya dipahatkan pada batu atau kadang-kadang dituliskan pada daun-daun papyrus.

Ciri-ciri pendidikan pada masa Mesir Purba: 1. sumber pengetahuan ialah kumpulan-kumpulan nyanyian pujaan pada dewa-dewa; 2. yang menyelenggarakan pendidikan adalah kasta pendeta. Hanya para pendeta dan prajurit yang dapat menikmati pendidikan. Tujuan pendidikan pada masa itu adalah: bersifat susila-keagamaan. Semua aktivitas manusia akhirnya bermaksud berbakti kepada dewadewa. Pelajaran yang diutamakan di Mesir pada masa klasik adalah membaca, menulis, berhitung, bahasa, ilmu ukur tanah, ilmu alam, ilmu binatang, bergulat, bersenam, dan musik. Buku sumber yang digunakan adalah buku-buku hermetis, yaitu buku suci yang jumlahnya 42 buah yang berasal dari dewa Toth (Yunani: Hermes). Pusat pendidikan disebut sekolahsekolah kuil dan merupakan pusat-pusat kuliah yang 
teratur. Seluruh organisasi kuil disebut kesatuan rumah Seti, yang di dalamnya terdapat pula perpustakaan, asrama, dan sekolah rendah (untuk anak warga negara bebas).

\section{Pendidikan Di Abad Pertengahan}

Abad pertengahan merupakan jaman scholastik (pelajaran sekolah). Scholastik dimaksud sebagai usaha ilmiah untuk membuat supaya pelajaran-pelajaran gereja dapat dipahami dengan memberikan bukti-bukti yang logis. Kehidupan duniawi dianggap hanya sebagai landasan bagi hidup di alam baka. Apabila di Yunani dan Romawi ada orang tunduk pada negara, maka kini tunduk pada gereja.

Abad pertengahan di Eropa dibagi menjadi dua bagian yang berlainan keadaannya. Abad ke-5 dan ke-6 disebut abad gelap. Pada masa itu terjadi perpindahan bangsa-bangsa, kekacauan, dan bangkitnya kebudayaan. Sesudah perang salib, timbullah bagian kedua dari jaman tengah ini dengan timbulnya kota-kota, dan budak belian dibebaskan sekembalinya dari perang Palestina. Pada bagian kedua inilah awal munculnya universitas.

Dalam masa abad gelap di seluruh Eropa terjadi perpindahan bangsa-bangsa dari timur ke Barat dan dari Utara ke Selatan. Pada abad ke-7 terjadi pula perpindahan bangsa-bangsa baru dari tanah Arab melalui Mesir, Afrika, menyeberang ke Spanyol dan Prancis. Mula-mula akan mengalahkan bangsa Barat, tapi pada tahun $732 \mathrm{M}$ dapat dikalahkan oleh bangsa Prancis.

Beberapa aliran yang mempengaruhi pendidikan dan pengajaran antara lain: Religi, Renaissance, Reformasi, Rationalisme, dan Sosialisme. Aliran-aliran tersebut tidak terpisah satu sama lain, akan tetapi yang satu merupakan reaksi atas aliran sebelumnya, dan saling mempengaruhi. Pada abad pertengahan, aliran religi 
menjadi sangat berpengaruh. Pendidikan bersifat akhirat, hal-hal yang sifatnya duniawi tidak begitu mendapat perhatian. Semua usaha pendidikan tertuju kepada kehidupan akhirat.

Yang menjadi lembaga pendidikan adalah: rumah tangga, gereja, sekolah, negara, dan masyarakat. Semua lembaga tersebut didominasi oleh religi. Agama merupakan pusat dari seluruh pendidikan dan pengajaran. Pekerjaan para paderi yang semula mengerjakan tanah, mengeringkan paya-paya guna memajukan pertanian, beralih ke penyelenggaraan kepentingan-kepentingan rohaniah, yaitu dengan didirikannya sekolah-sekolah. Sekolah-sekolah yang didirikan pada abad pertengahan antara lain: Sekolah Biara, Sekolah Kathedral, Sekolah Istana, Sekolah Cathecismus dan Sekolah Parochi (sekolah nyanyi).

Beberapa sekolah biara terbaik diperluas dan dipertinggi mutu pelajarannya. Sehingga berdirilah universitas-universitas yang pertama: 1. universitas di Salerno: untuk ketabiban; 2. universitas di Bologna: untuk ilmu hukum; 3. universitas di Paris: untuk theologi. Perguruan tersebut hanya mempunyai satu fakultas, yaitu: sekolah tinggi. Metode yang dipakai adalah metode scholastik: maha guru mempergunakan buku tertentu, misalnya: Corpus Juris, kemudian pelajar membuat diktat. Setelah itu diadakan penjelasan dan pembicaraan. Atas inisiatif raja, paus, dan orang-orang terkemuka jumlah universitas semakin lama semakin bertambah banyak.

Kelemahan-kelemahan abad pertengahan: 1) semua sekolah diperintah oleh gereja dan paderi; 2). semua pelajaran dan pendidikan hanya untuk kepentingan gereja dan paderi; 3) kehidupan sehari-hari tidak mendapt perhatian sebagaimana mestinya; 4) yang diselenggarakan adalah pengetahuan yang telah ada, 
yang berasal dari ahli-ahli Yunani dan Romawi, sehingga tidak ada perkembangan dan kemajuan ilmu pengetahuan; 5) metode mengajar formalistis: menghafal tepat seperti yang terdapat dalam buku secara mekanis. Oleh sebab itu seringkali bersifat verbalistis.

\section{Perkembangan Pendidikan Abad Moderen}

Pada abad ini, pendidikan mengalami kemajuan yang sangat pesat. Beberapa penyebab terjadinya kemajuan tersebut adalah: pertama. Revolusi Prancis. Revolusi prancis yang terjadi sejak tahun 1789, berupa kebangkitan kasta ketiga menimbulkan gelombang demokrasi hampir di seluruh Eropa. Kasta ini menuntut hak-haknya di lapangan politik, diikuti pula adanya perlawanan terhadap kaum bangsawan dan agama. Perlawanan ini muncul akibat meluasnya cita-cita pencerahan, yang mengemukakan teori tentang manusia yang mempunyai derajat sama, tidak terpengaruh oleh kelahiran, kasta, atau kepercayaan. Semboyan kebebasan, persamaan, dan persaudaraan bergema di sluruh dunia Barat.

Kedua Revolusi Industri, Perkembangan ilmu pengetahuan, khususnya ilmu-ilmu alam menyebabkan perubahan besar di sektor industri. Perkembangan teknik menghasilkan penemuan-penemuan baru dan memungkinkan munculnya berbagai industri, yang sebelumnya dikerjakan dengan tangan, mulai dikerjakan dengan mesin. Pabrik-pabrik tumbuh di mana-mana. Revolusi industri ini dimulai di Inggris, kemudian tersebar luas hingga pada abad ke-19 pengaruhnya tampak di hampir seluruh dunia.

Beberapa tokoh pendidikan yang besar pengaruhnya pada abad ke-19, yaitu: 1) Johan Heinrich Pestalozzi (1746-1827) dilahirkan di Zurich (Swiss). Citacita pendidikan Pestalozzi adalah; menghendaki 
pendidikan yang disesuaikan dengan perkembangan jiwa anak. Bakat yang dibawa anak sejak lahir harus dikembangkan, sehingga anak dapat mencapai kepribadian yang sejati. Tugas pendidik adalah menolong anak dalam pembentukan diri sendiri. 2) Johann Friedrich Herbart (1776-1841) lahir di Oldenburg (Jerman). Herbart adalah seorang pelopor yang terbesar dari intelektualisme, yaitu sebuah paham bahwa kemajuan di bidang rohaniah hanya dapat dicapai melalui akal dan pengetahuan saja. 3) Friedrich Frobel (1782-1852) dilahirkan di Thuringen (Jerman) pada 1782. Dia pertama kali mendirikan sebuah sekolah bagi anakanak kecil pada tahun 1837 di Blankenburg, yang dinamakannya "kindergarten" (Taman Kanak-kanak). Di sekolah tersebut diutamakan bermain, menyanyi dan pekerjaan tangan.

\section{Sejarah Pendidikan di Indonesia}

\section{Pendidikan di Indonesia pada Masa Hindu-Buddha.}

Pada masa pra kolonial, pendidikan di Nusantara diwarnai oleh pengaruh kerajaan yang bercorak HinduBudha dan dilanjutkan oleh pengaruh Islam di Nusantara (Syaharuddin dan Susanto, 2019). Berdasarkan prasasti peninggalan Raja Mulawarman (abad 4 - 5 M) di Kutai dalam bahasa Sansekerta menunjukkan adanya pengaruh agama Siwa. Demikian juga peninggalan Purnawarman di Jawa Barat dalam bahasa yang sama, diketahui bahwa di Jawa Barat pernah berdiri kerajaan Tarumanegara. Prasati-prasasti tersebut didirikan para pendeta dari golongan Brahmana (Leo Agung dan T. Suparman, 2012). Menurut Sihombing (1962), pada masa tersebut hanya golongan brahmana saja yang dapat menggunakan bahasa Sansekerta sebagai bahasa resmi dan membaca kitab-kitab suci seperti Weda. Sehingga dapat dikatakan, 
pendidikan hanya ditujukan pada golongan yang berkasta tinggi saja.

Selanjutnya pada abad ke-6 Kerajaan Sriwijaya di Sumatera menjadi pusat agama Budha. Raja- raja Sriwijaya wangsa Syailendra dan beragama Buddha. Empat buah batu bertulis ditemukan di Palembang, Jambi dan Bangka. Semuanya ditulis dalam huruf Pallawa di dalam bahasa Melayu tua bercampur perkataan-perkataan Sanskerta (Leo Agung, 2012). Hingga permulaan abad 11 kerajaan Sriwijaya masih merupakan pusat pengajaran agama Buddha yang bertaraf internasional. Rajanya saat itu bernama Sri Cudamaniwarman dan mengaku dirinya dari Dinasti Syailendra.

Pendidikan yang berbasis agama Buddha pada Abad ke-7 juga telah berkembang di Jawa (Ardhan, 2012). Berdasarkan catatan perjalanan I-Tsing seorang pendeta Tiongkok yang pernah belajar ilmu aturan Sansekerta di Sriwijaya sekitar tahun 671 M (Soebantardjo, 1957) menuliskankan bahwa, pada masa itu seorang pendeta Tionghoa bernama Hwi-Ning pernah menerjemahkan beberapa kitab suci agama Budha dari bahasa Sansekerta ke bahasa Tionghoa dengan bantuan seorang pujangga sastra Jawa Kuno yang bernama pendeta Jnanabhadra. Dari berita ini menunjukkan bahwa di daerah Jawa juga menjadi rujukan bagi pendeta yang berasal dari daerah lain untuk mempelajari agama dengan para pendeta yang berasal dari Indonesia (Ardhan, 2012).

Baru pada abad ke-8 terutama di Mataram kuno didapatkan bahan-bahan yang lebih memberi pengertian tentang pendidikan dan pengajaran. Di Candi Borobudur terlihat lukisan yang menggambarkan suatu sekolah seperti yang berlaku pada waktu sekarang. Di tengahtengah pendapa besar seorang Brahmana duduk dilingkari oleh murid-murid, semua membawa buku. 
Mereka belajar membaca dan menulis. Murid-murid tinggal bersama-sama dengan Brahmana dalam suatu rumah. Gurunya tidak menerima gaji, dijamin oleh siswanya untuk hidup (Leo Agung and T. Suparman, 2012).

\section{Pendidikan di Indonesia pada Zaman Penyebaran Islam}

Pada awal abad ke-16 dan sebagian sumber bahkan menuliskan abad ke-13, banyak masyarakat yang dahulu memeluk agama Hindu kemudian memeluk agama Islam. Mungkin saja agama Islam yang mereka anut masih menyesuaikan dengan keadaan dan adat istiadat masyarakat pada saat itu atau mungkin juga masih menyesuaikan dengan kebudayaan Hindu (Leo Agung and T. Suparman, 2012). Proses penyebaran Islam dilakukan dengan berbagai jalan, mulai dari perdagangan, pernikahan, pengobatan, budaya, maupun pendidikan (Rifa'i, 2011).

Lembaga pendidikan Islam telah memainkan fungsi dan perannya sesuai dengan tuntutan masyarakat pada zamannya. Adapun lembaga pendidikan di Indonesia pada zaman penyebaran Islam antara lain: pertama Pendidikan Masjid, Langgar, dan Surau; Hampir di setiap desa di Pulau Jawa terdapat tempat peribadatan. Di tempat tersebut, selain merupakan tempat beribadah juga menjadi tempat belajar tentang dasar-dasar agama, mulai dari membaca dan menulis huruf Arab serta mempelajari isi Al-Quran (Rifa'i, 2011). Selain langgar di pulau jawa, sekolah agama di Sumatera khususnya di Minangkabau disebut dengan "Surau" yang memberikan pelajaran permulaan dan pelajaran tinggi (Nizar, 2011). Istilah surau di Minangkabau sudah dikenal sebelum datangnya Islam. Sebagai lembaga pendidikan tradisional, surau menggunakan sistem 